\title{
REMOVAL OF IRON FROM WATER USING HYDROGEN PEROXIDE
}

\author{
Hewahy, M. A. ${ }^{(1)}$; Jahin, H. S. ${ }^{(2)}$ and Hesham, A. M
}

1) Basic Sciences department, Institute of Environmental Studies and Research, Ain Shams University 2) Central laboratory for Environmental Quality Monitoring, National Water Research Center.

\begin{abstract}
The presence of iron is probably the most common water problem facing by consumers. So, the aim of this study was to assess the efficacy of hydrogen peroxide to remove iron $(\mathrm{Fe} 2+)$ from water. Water with high content of $\mathrm{Fe} 2+(20 \mathrm{ppm}$ of iron II) was prepared in the laboratory using Iron(II) sulfate heptahydrate (FeSO4.7H2O), then treated with $0,0.1,1,3,5$, 10 and $20 \mathrm{ppm}$ of hydrogen peroxide as the final concentration in the solution for contact time 5, 10, 20, 30 and 60-minute. Results showed that the average of removal ratio of $\mathrm{Fe} 2+$ was $85 \%-96 \%$ at the normal $\mathrm{pH}$ range of drinking water. The recommended dose of hydrogen peroxide was $0.1 \mathrm{ppm}$ as a final concentration for 20-minute contact time. The study proved that hydrogen peroxide successfully used for Iron II removal and consider as economic and eco-friendly solution.
\end{abstract}

Keywords: Hydrogen peroxide, Heavy metals, Water, Iron removal, Oxidation

\section{INTRODUCTION}

All of us believe that there is no life without water, in the fact it is wellknown that clean water considers the absolutely essential thing for the people (Kroehler, 2013). In the past, rain was one of the main sources of freshwater because it forms rivers and lakes. Rain is commonly polluted by various pollutants that we add to our atmosphere. Enough renewed, clean and 
obtainable drinking water is a basic requirement for the life of all organisms on the earth's surface (Ahuja, 2013).

Heavy metals (such as arsenic, zinc, manganese, aluminum, cadmium, lead and others) cause many health problems if they are found in drinking water at concentrations higher than permitted (Kroehler,2013) and (Fernández-luqueño et al., 2013).

Heavy metals are widely different in their chemical properties, also it is important in our everyday life, as well as in high-tech applications. This gives chance for heavy metals to reach and enter into our aquatic food chains from different anthropogenic natural weathering sources (Tripathi \& Ranjan, 2015).

Contamination basically from mining wastes, landfill, wastewater, industrial waste, particularly from the electroplating and metal finishing (Huang et al., 2016).

The problems are becoming larger because metals have ability to be transported with sediments, and can bio-accumulate in the food chain (Fernández-luqueño et al., 2013).

Besides that, iron in an industrial water lead to many problems such as corrosion of boiler water, cooling water lines due to the presence of high concentrations and also membranes stations damage reverse osmosis if not get rid of iron in the feed water (Sharma, 2015). The world health organization (WHO) recommends that iron concentration in drinking water should be less than $0.3 \mathrm{mg} / \mathrm{L}$ (WHO, 1996). The European commission directive recommends that iron in water supplies should be less than $0.2 \mathrm{mg} / \mathrm{L}$ 
(Council Directive /EC, 1998). The Egyptian limits for iron in drinking water is $0.3 \mathrm{mg} / \mathrm{L}$ (Law 48, 2003).

Iron usually exists in two oxidations states, ferrous $\left(\mathrm{Fe}^{+2)}\right.$ and ferric $\left(\mathrm{Fe}^{+3}\right)$. Several methods such as lime softening, ion exchange, activated carbon, oxidation, precipitation, bioremediation and membrane process have been used for the removal of iron from water (Cho, 2005).

Hydrogen peroxide is considered as ecofriendly substance and has highly oxidation capacity. So, it was used to remove heavy metals from industrial wastewater (Weakley, 2009). It is one of the most powerful oxidizers known, stronger than chlorine, chlorine dioxide and potassium permanganate ( Ayres et al., 2013).

Hydrogen peroxide can be converted to hydroxyl radical $(\mathrm{OH}$.$) with$ reactivity second only to fluorine. However, literature review indicated that very few studies has been conducted to find out the effects of factors that contribute to hydrogen peroxide decomposition in wastewater treatment. Such factors include contact time, $\mathrm{pH}$ and $\mathrm{H}_{2} \mathrm{O}_{2}$ dose. Hence, the objective of this study to investigate the concentration of hydrogen peroxide and contact time required to remove the $\mathrm{Fe}^{2+}$ ions from water.

\section{MATERIAL AND METHODS}

1. Chemicals: The reagents and synthetic solutions used in this study were all prepared by use of analytical grade chemicals, which were supplied from MERK Co. as follows: Iron (II) sulfate heptahydrate, Nitric acid, Sodium Hydroxide and Hydrogen peroxide $30 \%$ W/V. 
2. Instruments: Inductively Coupled Plasma-Emission Spectrometry (ICPES) (Perkin Elmer optima 3000, USA) for Iron analysis. 2. pH meter (ORION model 710A). 3. Analytical balance, Mettler Toledo model AL 104. 4. Digital Thermometer, Conductivity Meter / TDS Meter, HANNA, model HI993310. model: Checktemp - HI98501. 5. Conductivity Meter / TDS Meter, HANNA, model HI993310.

3- Preparation of various $\mathrm{H}^{2} \mathrm{O}^{2}$ concentrations: The amount taken from the stock solution of $\mathrm{H}^{2} \mathrm{O}^{2}$ to prepare different concentration as required concentration explained in Table (1).

Table (1): Preparation of different concentrations of $\mathrm{H} 2 \mathrm{O} 2$

\begin{tabular}{|c|c|c|c|}
\hline $\begin{array}{l}\text { Stock solution } \\
\text { of } \mathrm{H}_{2} \mathrm{O}_{2}\end{array}$ & $\begin{array}{c}\mathrm{V} \text { from } \mathrm{H}_{2} \mathrm{O}_{2} \\
\text { stock solution } \\
\mathrm{ml} \\
\end{array}$ & $\begin{array}{c}\text { Water with } \\
\text { high content of } \\
\text { iron }\end{array}$ & $\begin{array}{c}\text { The final } \\
\text { concentration of } \\
\mathrm{H}_{2} \mathrm{O}_{2} \\
\end{array}$ \\
\hline $\mathrm{H}_{2} \mathrm{O}_{2} \quad 30 \%$ & $0.3 \mathrm{ml}$ & $999.7 \mathrm{ml}$ & $100 \mathrm{ppm} \mathrm{H}_{2} \mathrm{O}_{2}$ \\
\hline $\mathrm{H}_{2} \mathrm{O}_{2} \quad 30 \%$ & $3 \mathrm{ml}$ & $997 \mathrm{ml}$ & $1000 \mathrm{ppm} \mathrm{H}_{2} \mathrm{O}_{2}$ \\
\hline $100 \mathrm{ppm}$ & $1 \mathrm{ml}$ & $999 \mathrm{ml}$ & $0.1 \mathrm{ppm} \mathrm{H}_{2} \mathrm{O}_{2}$ \\
\hline $1000 \mathrm{ppm}$ & $1 \mathrm{ml}$ & $999 \mathrm{ml}$ & $1 \mathrm{ppm} \mathrm{H}_{2} \mathrm{O}_{2}$ \\
\hline 1000 ppm & $3 \mathrm{ml}$ & $997 \mathrm{ml}$ & 3 ppm $\mathrm{H}_{2} \mathrm{O}_{2}$ \\
\hline $1000 \mathrm{ppm}$ & $5 \mathrm{ml}$ & $995 \mathrm{ml}$ & $5 \mathrm{ppm} \mathrm{H}_{2} \mathrm{O}_{2}$ \\
\hline $1000 \mathrm{ppm}$ & $10 \mathrm{ml}$ & $990 \mathrm{ml}$ & $10 \mathrm{ppm} \mathrm{H}_{2} \mathrm{O}_{2}$ \\
\hline $1000 \mathrm{ppm}$ & $20 \mathrm{ml}$ & $980 \mathrm{ml}$ & $20 \mathrm{ppm} \mathrm{H}_{2} \mathrm{O}_{2}$ \\
\hline
\end{tabular}

4- Preparation of water with high content of iron II: To prepare 1 liter of water contained high content of iron II, 0.1837 gm. accurately weighted from Iron (II) sulfate heptahydrate $\mathrm{FeSO} 4.7 \mathrm{H} 2 \mathrm{O}$ and dissolved in a little quantity of distilled water then completed to one liter by distilled water, 
one drop added from nitric acid to be sure all Iron(II) sulfate heptahydrate is dissolved.

5- Treatment: For bench-scale experiments, synthetic samples of Iron $(\mathrm{Fe}+2)$ had been used instead of real water samples. All these experiments had been carried out in reactor followed with $20 \mu$ cartridge filter with capacity of 1 liter and variables studied include $\mathrm{pH}$, contact time and $\mathrm{H}_{2} \mathrm{O}_{2}$ concentrations as shown in Fig. (1).

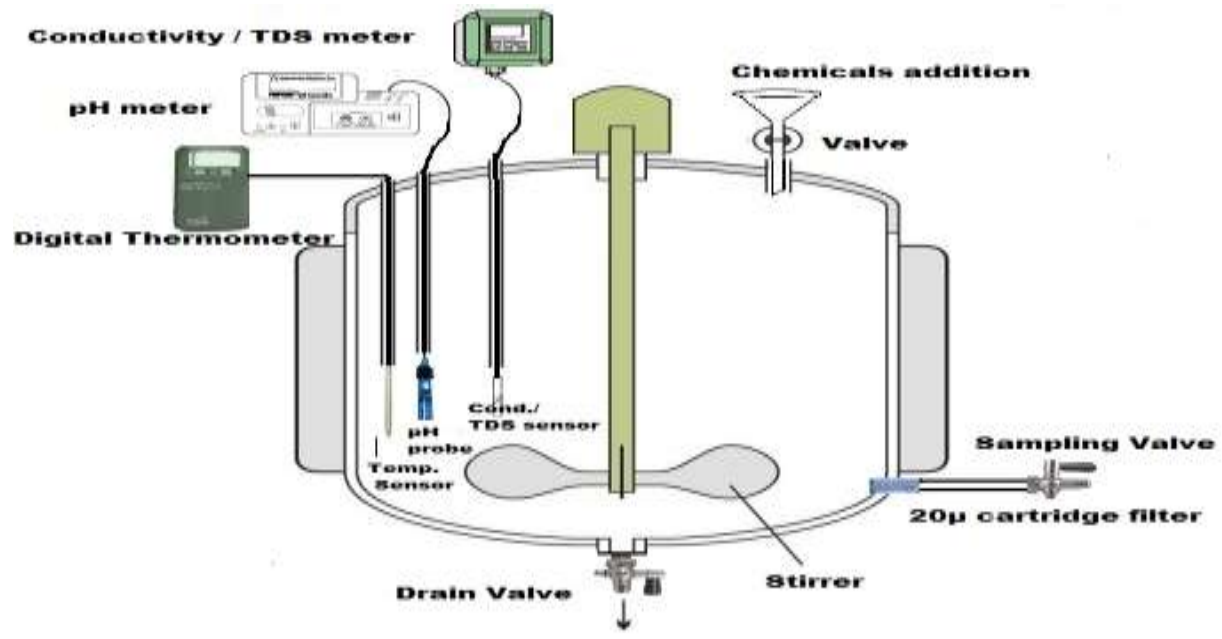

Figure(1): Bench scale reactor combined with $20 \mu$ filter 


\section{RESULTS AND DISCUSSIONS}

\section{Removal of iron without $\mathrm{H}_{2} \mathrm{O}_{2}$}

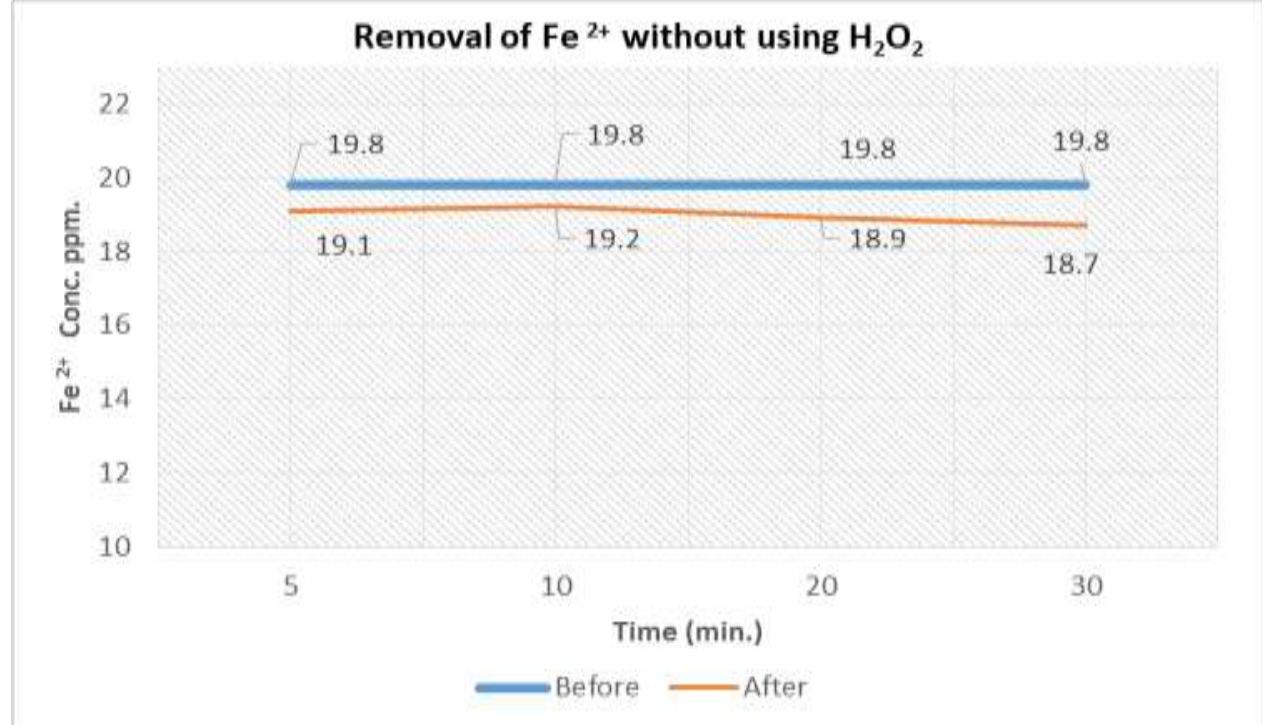

Figure (2): removal of $\mathrm{fe}^{+2}$ without using $\mathrm{h}_{2} \mathrm{O}_{2}$

The removal of iron from the prepared water without any addition of $\mathrm{H}_{2} \mathrm{O}_{2}$ as a control for the other parameters to check the effect of $\mathrm{H}_{2} \mathrm{O}_{2}$ under different concentrations, after 5, 10, 20, 30 and 60-minutes, the removal percentage of iron II was $1.5,3.5,3.0,4.5$ and $5.6 \%$ respectively as shown in Fig. (2).

2. Removal of iron with $\mathbf{0 . 1}$ ppm H2O2: The removal of iron from the prepared water with $0.1 \mathrm{ppm}$ of $\mathrm{H}_{2} \mathrm{O}_{2}$ after $5,10,20,30$ and 60 minutes were studied, the removal percentage of iron II were 83.8, 84.3, 85.4, 85.9 and $85.9 \%$ respectively as shown in Table (2). 
Table (2): Removal of $\mathrm{Fe}^{2+}$ with o.1 ppm $\mathrm{H}_{2} \mathrm{O}_{2}$

\begin{tabular}{|c|c|c|c|c|c|}
\hline \hline S.no & $\begin{array}{c}\text { Fe II conc. } \\
\text { Initial }\end{array}$ & $\begin{array}{c}\text { Conc. of } \\
\mathbf{H}_{\mathbf{2}} \mathbf{O}_{\mathbf{2}}\end{array}$ & $\begin{array}{c}\text { Contact } \\
\text { time (min) }\end{array}$ & $\begin{array}{c}\text { Fe II conc. } \\
\text { Final }\end{array}$ & Remv.\% \\
\hline \hline 1 & 19.8 & 0.1 & 5 & 3.2 & 83.8 \\
\hline 2 & 19.8 & 0.1 & 10 & 3.1 & 84.3 \\
\hline 3 & 19.8 & 0.1 & 20 & 2.9 & 85.4 \\
\hline 4 & 19.8 & 0.1 & 30 & 2.8 & 85.9 \\
\hline 5 & 19.8 & 0.1 & 60 & 2.8 & 85.9 \\
\hline Mean & 19.8 & & & 2.96 & 85.1 \\
\hline Min & 19.8 & & & 2.8 & 83.8 \\
\hline Max & 19.8 & & & 3.2 & 85.9 \\
\hline S.D & 0 & & & 0.18 & 0.92 \\
\hline
\end{tabular}

3. Removal of iron with 1 ppm $\mathrm{H} 2 \mathrm{O} 2$

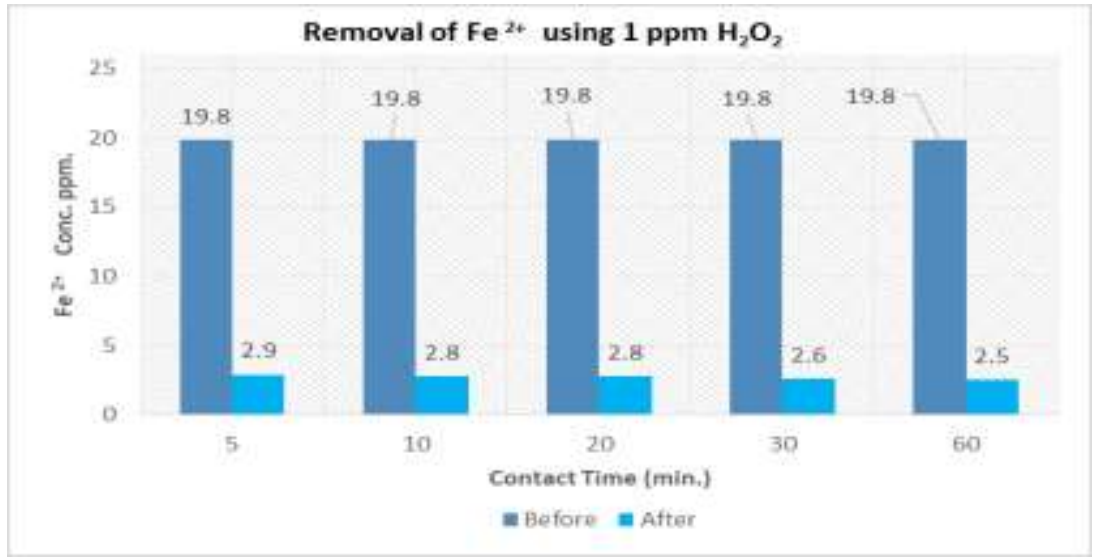

Figure (2): Removal of $\mathrm{Fe}^{2+}$ using 1 ppm $\mathrm{H}_{2} \mathrm{O}_{2}$

The removal of iron from the prepared water with 1 ppm of $\mathrm{H}_{2} \mathrm{O}_{2}$ after 5, 10, 20, 30 and 60 minutes were studied, the removal percentage of iron II were 85.4, 85.9, 85.9, 86.9 and 87.4\% respectively as shown in Fig. (3). 
4. Removal of iron with 3 ppm $\mathrm{H}_{2} \mathrm{O}_{2}$ : The removal of iron from the prepared water with $3 \mathrm{ppm}$ of $\mathrm{H}_{2} \mathrm{O}_{2}$ after 5, 10, 20, 30 and 60 minutes were studied, the removal percentage of iron II were $88.9,89.4,89.9,89.4$ and $89.9 \%$ respectively as shown in Table (3).

Table (3): Removal of $\mathrm{Fe}^{2+}$ with 3 ppm $\mathrm{H}_{2} \mathrm{O}_{2}$

\begin{tabular}{|c|c|c|c|c|c|}
\hline S.no & $\begin{array}{c}\text { Fe II } \\
\text { conc. } \\
\text { Initial }\end{array}$ & $\begin{array}{c}\text { Conc. of } \\
\mathbf{H 2 0 2}\end{array}$ & $\begin{array}{c}\text { Contact } \\
\text { time (min) }\end{array}$ & $\begin{array}{c}\text { Fe II } \\
\text { conc. final }\end{array}$ & Remv.\% \\
\hline \hline 11 & 19.8 & 3 & 5 & 2.2 & 88.9 \\
\hline 12 & 19.8 & 3 & 10 & 2.1 & 89.4 \\
\hline 13 & 19.8 & 3 & 20 & 2 & 89.9 \\
\hline 14 & 19.8 & 3 & 30 & 2.1 & 89.4 \\
\hline 15 & 19.8 & 3 & 60 & 2 & 89.9 \\
\hline Mean & 19.8 & & & 2.08 & 89.5 \\
\hline Min & 19.8 & & & 2 & 88.9 \\
\hline Max & 19.8 & & & 2.2 & 89.9 \\
\hline S.D & 0 & & & 0.08 & 0.42 \\
\hline
\end{tabular}

5. Removal of iron with 5 ppm $\mathrm{H}_{2} \mathrm{O}_{2}$ : The removal of iron from the prepared water with 5 ppm of ${ }_{2} \mathrm{O}_{2}$ after $5,10,20,30$ and 60 minutes were studied, the removal percentage of iron II were 91.9, 92.4, 91.9, 92.9 and $92.9 \%$ respectively as shown in Fig. (4). 


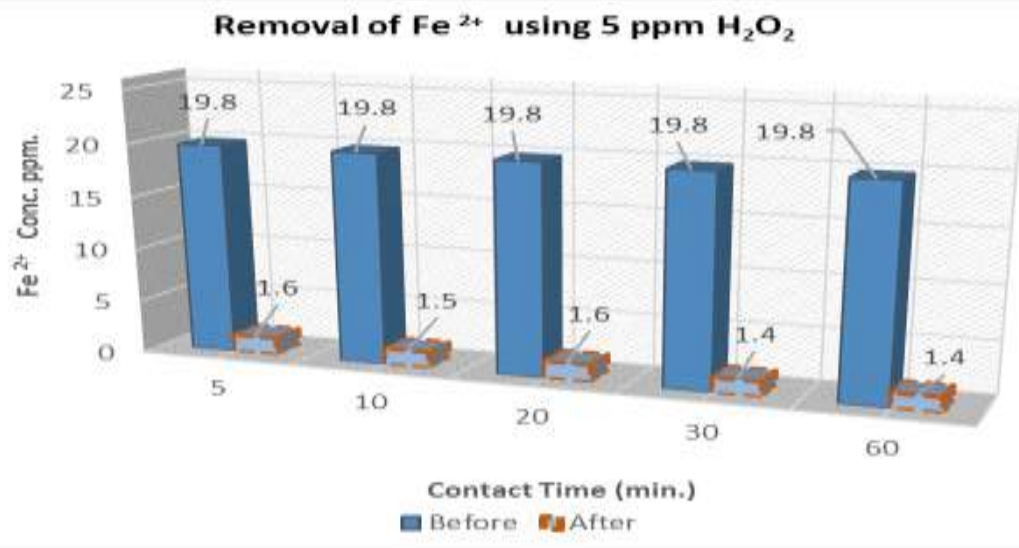

Figure (3): Removal of $\mathrm{Fe}^{2+}$ using $5 \mathrm{ppm}_{2} \mathrm{O}_{2}$

\section{Removal of iron with 10 ppm $\mathrm{H} 2 \mathrm{O} 2$}

Table (4): Removal of $\mathrm{Fe}^{2+}$ with 10 ppm $\mathrm{H}_{2} \mathrm{O}_{2}$

\begin{tabular}{|c|c|c|c|c|c|}
\hline S.no & $\begin{array}{c}\text { Fe II } \\
\text { conc. } \\
\text { Initial }\end{array}$ & $\begin{array}{c}\text { Conc. of } \\
\mathbf{H}_{\mathbf{2}} \mathbf{0}_{\mathbf{2}}\end{array}$ & $\begin{array}{c}\text { Contact } \\
\text { time (min) }\end{array}$ & $\begin{array}{c}\text { Fe II } \\
\text { conc. } \\
\text { final }\end{array}$ & Remv.\% \\
\hline \hline 21 & 19.8 & 10 & 5 & 1.2 & 93.9 \\
\hline 22 & 19.8 & 10 & 10 & 1.2 & 93.9 \\
\hline 23 & 19.8 & 10 & 20 & 1.3 & 93.4 \\
\hline 24 & 19.8 & 10 & 30 & 1.2 & 93.9 \\
\hline 25 & 19.8 & 10 & 60 & 1.1 & 94.4 \\
\hline Mean & 19.8 & & & 1.2 & 93.9 \\
\hline Min & 19.8 & & & 1.1 & 93.4 \\
\hline Max & 19.8 & & & 1.3 & 94.4 \\
\hline S.D & 0 & & & 0.07 & 0.36 \\
\hline
\end{tabular}

The removal of iron from the prepared water with $10 \mathrm{ppm}$ of $\mathrm{H} 2 \mathrm{O} 2$ after 5, 10, 20, 30 and 60 minutes were studied, the removal percentage of iron II were 93.9, 93.9, 93.4, 93.9 and 94,4\% respectively as shown in Table (4). 
7. Removal of iron with $20 \mathrm{ppm} \mathrm{H2O2:} \mathrm{The} \mathrm{removal} \mathrm{of} \mathrm{iron} \mathrm{from} \mathrm{the}$ prepared water with $20 \mathrm{ppm}$ of $\mathrm{H}_{2} \mathrm{O}_{2}$ after 5, 10, 20, 30 and 60 minute were studied, the removal percentage of iron II were 95.5, 95.5, 95.6, 95.6 and $95.8 \%$ respectively as shown in Fig. (5).

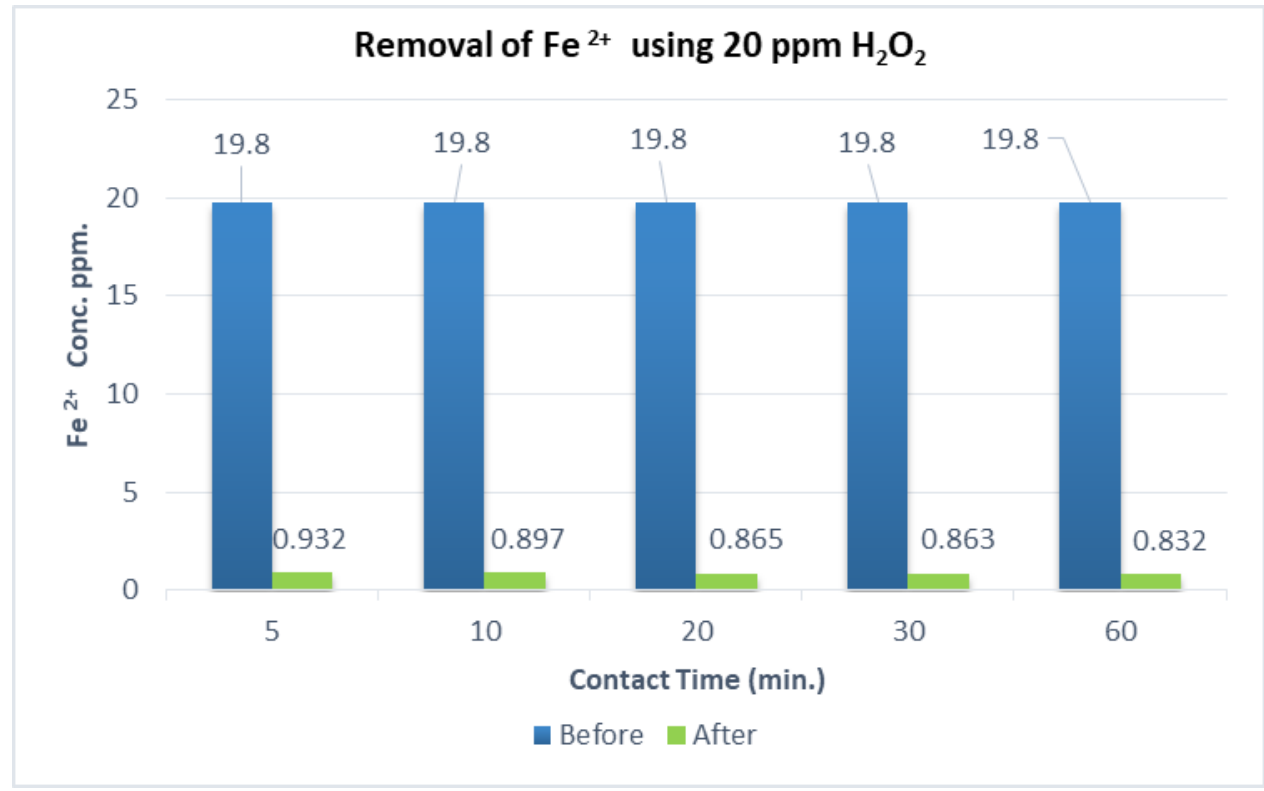

Figure(4): Removal of $\mathrm{Fe}^{2+}$ using $20 \mathrm{ppm}_{2} \mathrm{O}_{2}$

8. Average of removal of iron with H2O2: The average of removal of iron from the prepared water with $\mathrm{H}_{2} \mathrm{O}_{2}$ for $0,0.1,1,3,5,10$ and $20 \mathrm{ppm}$ of $\mathrm{H}_{2} \mathrm{O}_{2}$ in different contact time were calculated using SPSS v20 software. The average of removal percentage of iron II were 3.6, 85.1, 86.3, 89.5, 92.4, 93.9 and $95.6 \%$ respectively as shown in Fig. (6). 


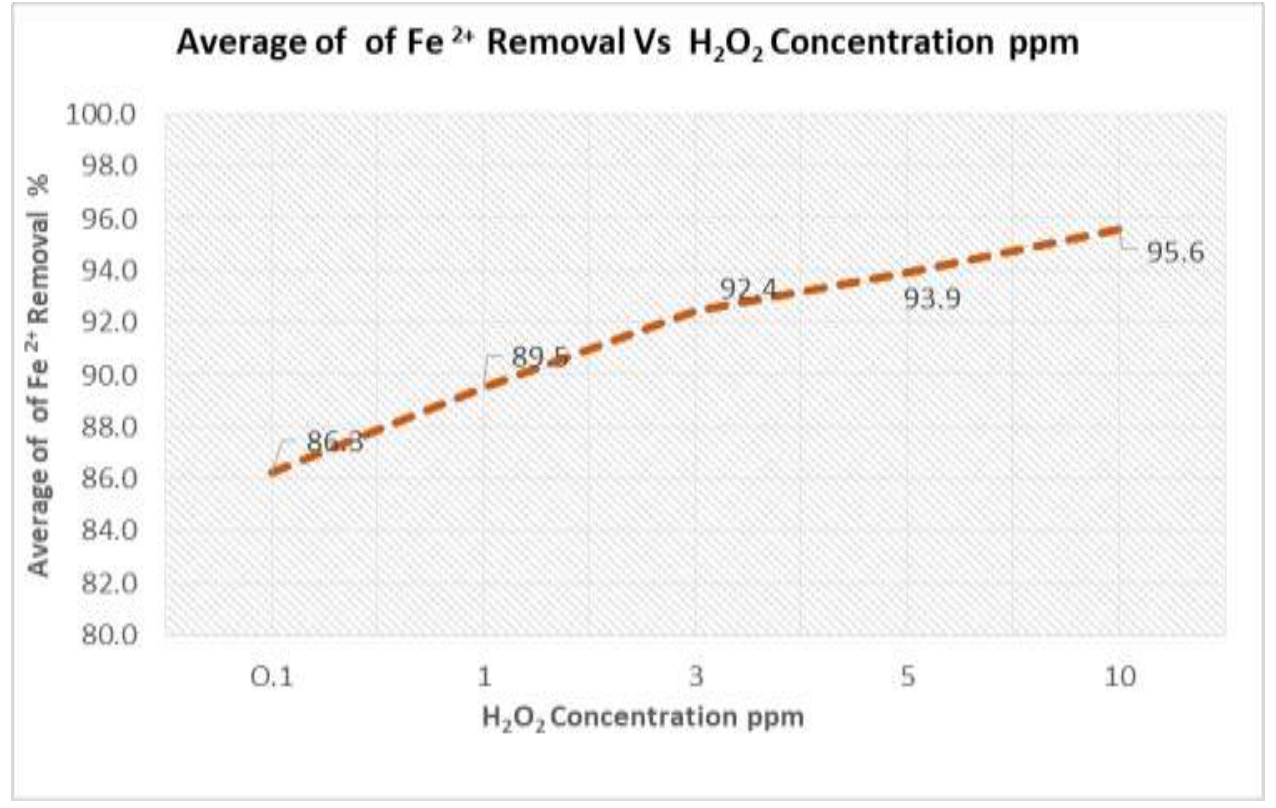

Figure(5): Average of $\mathrm{Fe}^{2+}$ removal $\mathrm{Vs}_{2} \mathrm{O}_{2}$ Conc. ppm

\section{Removal of iron with $\mathrm{H} 2 \mathrm{O} 2$ in different $\mathrm{pH}$ media}

Table(5): Removal of $\mathrm{Fe}^{2+}$ with $\mathrm{H}_{2} \mathrm{O}_{2}$ in different $\mathrm{pH}$ media

\begin{tabular}{|c|c|c|c|c|c|}
\hline $\mathbf{p H}$ & $\mathbf{F e}^{+\mathbf{2}}$ bef. & $\mathbf{H}_{\mathbf{2}} \mathbf{O}_{\mathbf{2}} \mathbf{~ p p m}$ & Time min. & $\mathbf{F e}^{+\mathbf{2}}$ Aft. & removal \% \\
\hline $\mathbf{3}$ & 20 & 20 & 5 & 19.3 & 3.5 \\
\hline $\mathbf{5}$ & 20 & 20 & 5 & 6.88 & 65.6 \\
\hline $\mathbf{7}$ & 20 & 20 & 5 & 2.68 & 86.6 \\
\hline $\mathbf{9}$ & 20 & 20 & 5 & 0.5 & 97.5 \\
\hline
\end{tabular}

The removal of iron from the prepared water with $\mathrm{H}_{2} \mathrm{O}_{2}$ in different $\mathrm{pH}$ with $20 \mathrm{ppm}$ of $\mathrm{H}_{2} \mathrm{O}_{2}$ for 5 minutes at $\mathrm{pH} 3,5,7$ and 9 were studied, the removal percentage of iron II were 3.5, 65.6, 86.6 and $97.5 \%$ respectively as shown in Table (5). 
10. Change in $\mathbf{p H}:$ : The results showed that slight change in $\mathrm{pH}$ values toward decrease the values, averages of values. The maximum change was from 7.4to 7.32. So it proves that the change of $\mathrm{pH}$ values not affect the usage of water and not need any other process to adjust $\mathrm{pH}$ again as shown in Fig (7).

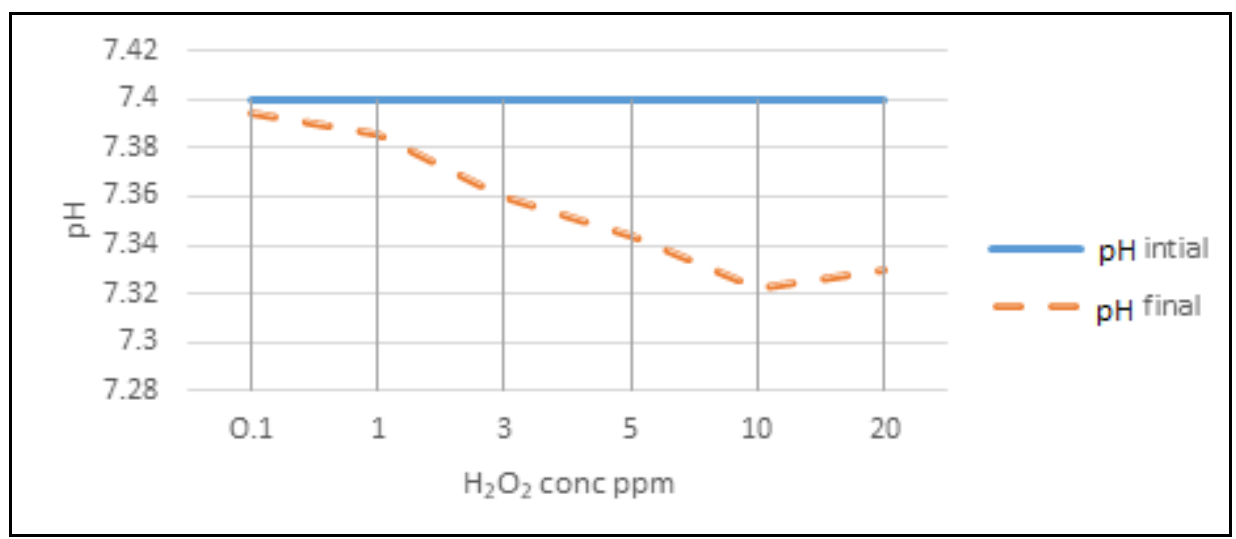

Figure(6): Change in $\mathrm{pH}$

11. Application on real water: Samples taken from a real water from Omar Beak drainage and applied the hydrogen peroxide on it, the Fe2+ decreased from $0.34 \mathrm{ppm}$ to $0.12,0.10,0.06 \mathrm{ppm}$ with $0.1,10,20 \mathrm{ppm}$ $\mathrm{H}_{2} \mathrm{O}_{2}$, the removal percentage was $64.71,70.59,79.41 \%$ respectively with 20-minute contact time as shown in Fig. (8). 


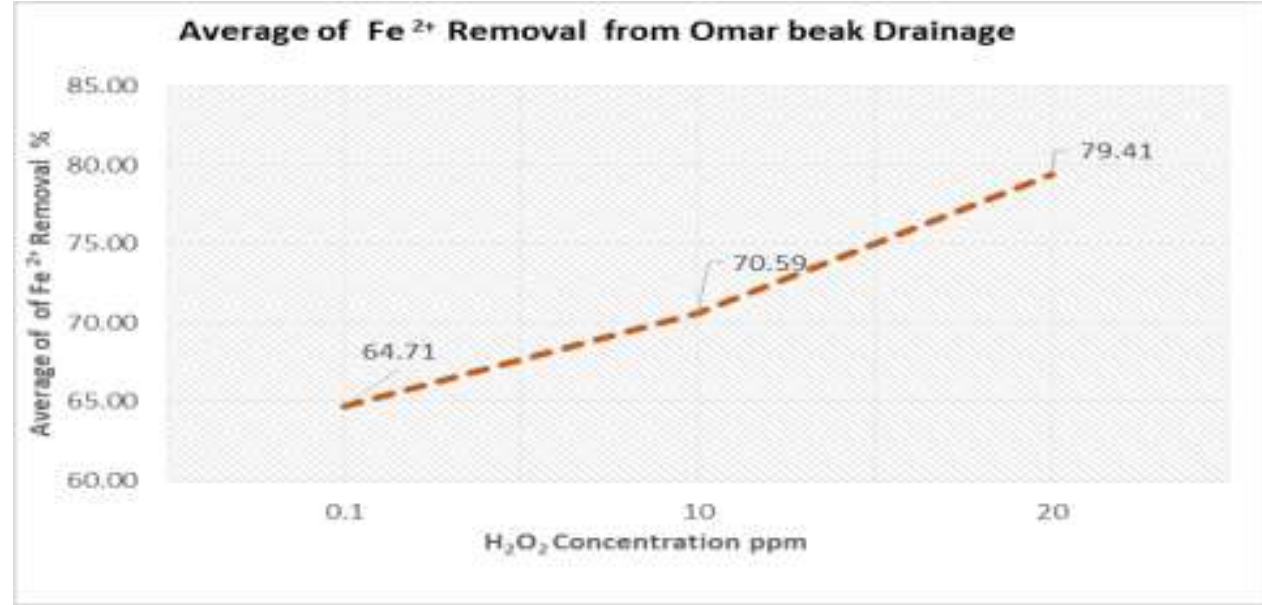

Figure(7): Average of $\mathrm{Fe}^{2+}$ removal from Omar beak Drainage samples

Samples taken from real water from intake of Zeftta drinking water treatment plant and applied the hydrogen peroxide on it, the $\mathrm{Fe}^{2+}$ decreased from $0.40 \mathrm{ppm}$ to $0.11,0.07,0.04 \mathrm{ppm}$ with $0.1,10,20 \mathrm{ppm} \mathrm{H} 2 \mathrm{O} 2$ the removal percentage was $72.50,82.50$, and $90.0 \%$ with $0.1,10,20$ ppm $\mathrm{H} 2 \mathrm{O} 2$ respectively with 20 minutes' contact time as shown in Fig. (9).

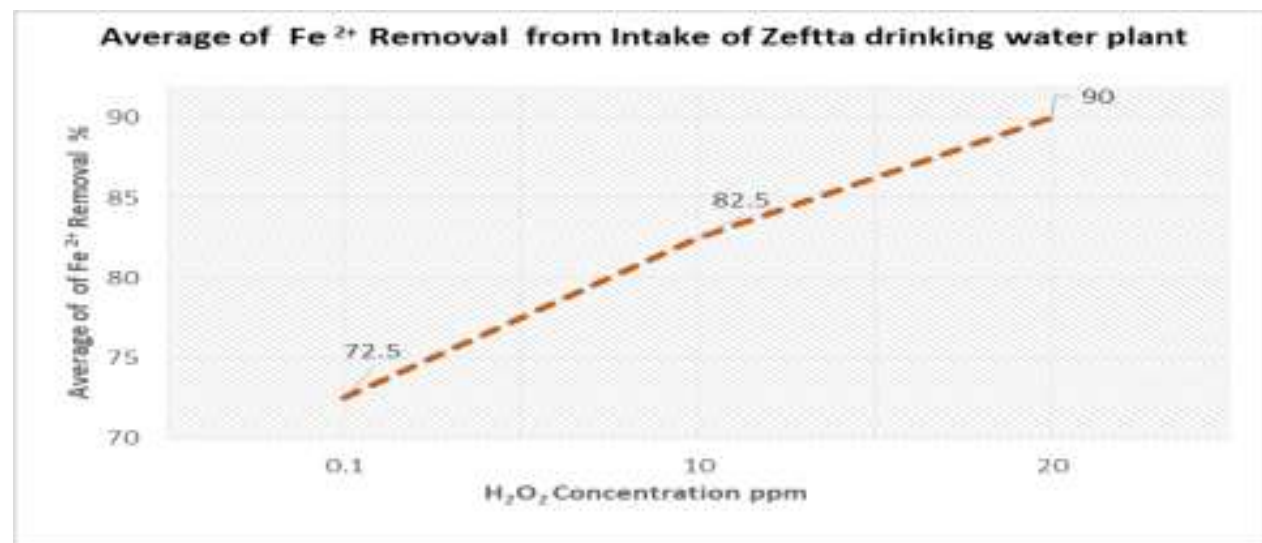

Figure(8): Average of $\mathrm{Fe}^{2+}$ removal from Intake of Zeftta drinking water plant Samples 
Effect of $\mathrm{H}^{2} \mathrm{O}^{2}$ concentration: The result leads to a relationship between hydrogen peroxide concentration and the iron removal percentage. The average of removal percentage of iron II were 3.6, 85.1, 86.3, 89.5, 92.4, 93.9 and $95.6 \%$ respectively with $0,0.1,1,3,5,10$ and 20 ppm of $\mathrm{H}_{2} \mathrm{O}_{2}$ as shown in Fig. (6).

Effect of Contact time: The result leads to a relationship between contact time with hydrogen peroxide and the iron removal percentage. The average of removal percentage of iron II were 95.5, 95.5, 95.6, 95.6 and $95.8 \%$ respectively after 5, 10, 20, 30 and 60 minute as contact time with $20 \mathrm{ppm}$ $\mathrm{H}_{2} \mathrm{O}_{2}$ as shown in Fig. (5).

Effect of pH: Result proved that the $\mathrm{pH}$ can be considered as a key factor in the iron removal with hydrogen peroxide. The removal percentages of iron II were $3.5,65.6,86.6$ and $97.5 \%$ respectively at $\mathrm{pH} 3,5,7$ and 9 with $20 \mathrm{ppm}$ of $\mathrm{H}_{2} \mathrm{O}_{2}$ for 5 minutes as shown in Table (5).

These results meet the theoretical expectation which showed that 1.01 ppm of $\mathrm{H}_{2} \mathrm{O}_{2}$ required removing $1 \mathrm{ppm}$ of $\mathrm{Fe}^{2+}$ as cited in iron and manganese removal handbook.

\section{CONCLUSION}

In the present study, the removal of iron $\left(\mathrm{Fe}^{+2}\right)$ from water using hydrogen peroxide was found to be effective. The removal ratio was increased with increasing the contact time. Hydrogen peroxide had a very slight effect on $\mathrm{pH}$ changes, the average of $\mathrm{pH}$ changes from 7.40 to 7.32. The results obtained from real samples show that hydrogen peroxide can be used effectively in the removal of iron from water. 


\section{REFRANCES}

Ahmad, M. (2012): Iron and manganese removal from groundwater. Geochemical Modeling of the Vyredox Method, Department of Geosciences, University of Oslo, Norway, 101p.

Ahuja, S. (Ed.). (2013): Monitoring water quality: Pollution assessment, analysis, and remediation. Newnes.

Al-Zoubi, H., Ibrahim, K. A., and Abu-Sbeih, K. A. (2015): Removal of heavy metals from wastewater by economical polymeric collectors using dissolved air flotation process. Journal of Water Process Engineering, 8, 19-27.

AWWA.(1999): USA. Standard Methods for the Examination of Water and Wastewater. (AWWA). Washington, DC: American Public Health Association.

Ayres, D. M., Davis, A. P., Gietka, P. M., Ibigbami, T. B., Dawodu, F. A., Akinyeye, O. J. and Imborvungu, J. A. (2013): Removal of heavy metals from industrial wastewater using hydrogen peroxide. African Journal of Biotechnology, 6(3), 485-496.

Cho, B. Y. (2005): Iron removal using an aerated granular filter. Process Biochemistry, 40(10), 3314-3320.

Directive, C. (1998): On the quality of water intended for human consumption. Off. J. Eur. Communities, L330.

Fernández-Luqueño, F., López-Valdez, F., Gamero-Melo, P., Luna-Suárez, S., Aguilera-González, E. N., Martínez, A. I., and PérezVelázquez, I. R. (2013): Heavy metal pollution in drinking watera global risk for human health: A review. African Journal of Environmental Science and Technology, 7(7), 567-584.

Huang, Y., Wu, D., Wang, X., Huang, W., Lawless, D., \& Feng, X. (2016): Removal of heavy metals from water using polyvinylamine by polymer-enhanced ultrafiltration and flocculation. Separation and Purification Technology, 158, 124-136.

Kroehler, C. J. (2014): Potable water quality standards and regulations: a historical and world overview. In Potable Water (pp. 1-36). Springer International Publishing. 
Sharma, S. K. (2015): Heavy metals in water: Presence, Removal and Safety. Royal society of chemistry. (RSC).

Song, Y., Lei, S., Zhou, J., and Tian, Y. (2016): Removal of heavy metals and cyanide from gold mine waste-water by adsorption and electric adsorption. Journal of Chemical Technology and Biotechnology, 91(9), 2539-2544.

Tripathi, A., and Rawat Ranjan, M. (2015): Heavy Metal Removal from Wastewater Using Low Cost Adsorbents. Journal of Bioremediation \& Biodegradation, 6(6), 1-5.

Weakley, I. I., and Allen, D. (2010): The removal of Manganese in drinking Water (Doctoral dissertation, University of Pittsburgh).

WHO Guidelines for Drinking Water Quality: Health Criteria and Other Supporting Information, 2nd ed., WHO, Geneva 1996.

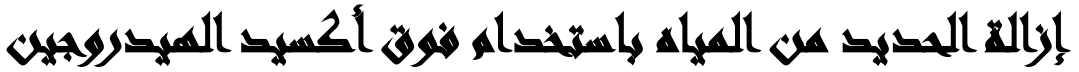

\section{[1]}

$$
\begin{aligned}
& \text { محمود أحمد حويحي(')- حسام الدين سمير جاهين(r)- أحمد محمد هشام }
\end{aligned}
$$

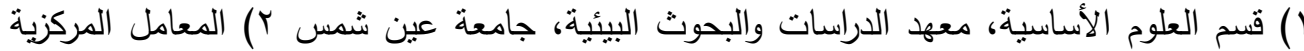

$$
\begin{aligned}
& \text { للرصد البييئ، المركز القومي لبحوث البئية المياه }
\end{aligned}
$$

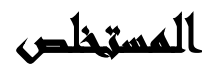

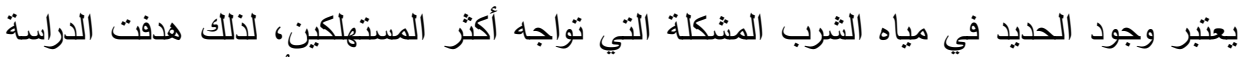

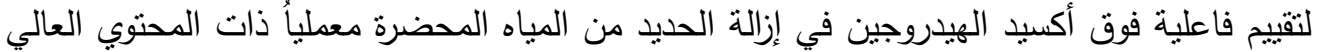

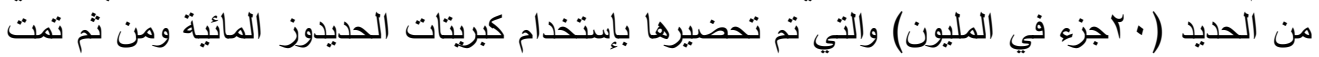

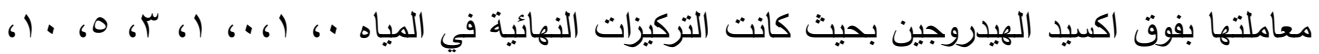

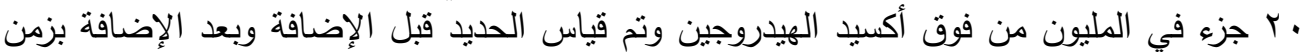

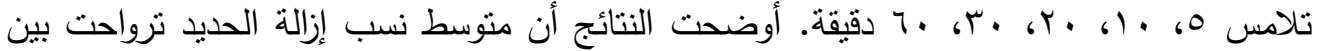

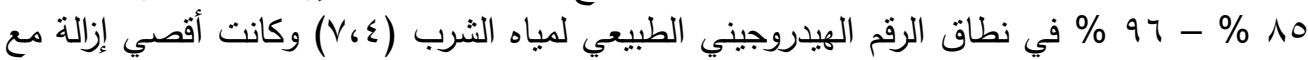

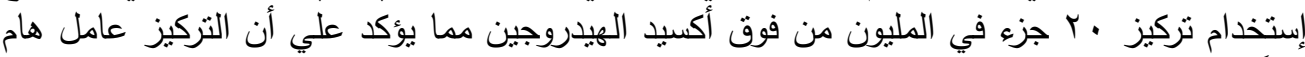

$$
\begin{aligned}
& \text { جداً في عملية الإزالة. كذلك زدات نسب الازالة بزيادة زمن التلامس وتكاد تكون الازالة طفيفة بعد التئ }
\end{aligned}
$$


مرور · r دقيقة من اضافة فوق أكسيد الهيدروجين مما يستوجب الحفاظ علي زمن تلامس · r دقيقة

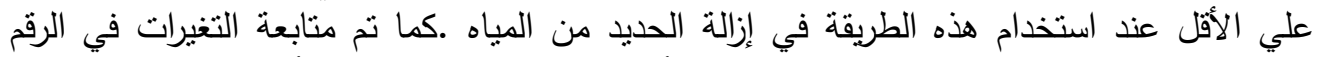

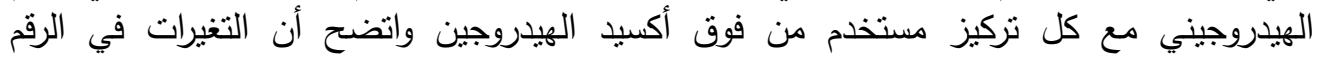

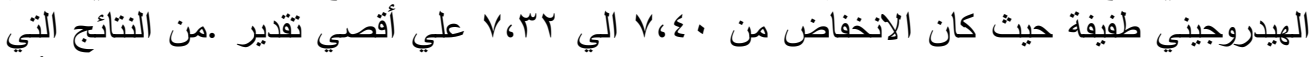

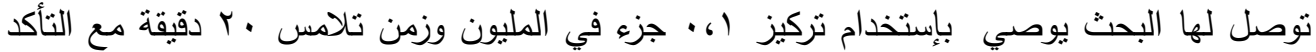

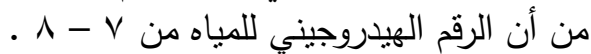
الكلمات الدالة: فوق أكسيد الهيدروجين، المبياه لعادن الثقيلة، مياه الثرب، إزالة الحديد، الأكسدة. 